Revistade
Economila
Contemporâned

\title{
SERÁ QUE "ACABOU O DINHEIRO"? FINANCIAMENTO DO GASTO PÚBLICO E TAXAS DE JUROS NUM PAÍS DE MOEDA SOBERANA ${ }^{1}$
}

\author{
Franklin Serrano ${ }^{a}$ \\ Kaio Pimentel \\ aProfessor do Instituto de Economia da Universidade Federal do Rio de Janeiro. \\ bEstudante do Doutorado em Economia do Instituto de Economia \\ da Universidade Federal do Rio de Janeiro.
}

Artigo recebido em 16/02/2017 e aprovado em 16/03/2017.

RESUMO: Este trabalho discute como se financiam os gastos públicos e se determinam as taxas de juros sobre os títulos de dívida pública de curto e longo prazo num país de moeda soberana. A análise segue a abordagem da taxa de juros exógena, que sintetiza os resultados comuns da visão da moeda endógena da Modern Monetary Theory e das finanças funcionais de Lerner. Focado particularmente no caso brasileiro, o trabalho começa com a análise dos procedimentos operacionais do financiamento do gasto público e a relação entre o Tesouro e o Banco Central, discute a relação entre financiamento do governo e as taxas de juros de títulos públicos de curto e longo prazo. Como um país (e não apenas o setor público) pode sim quebrar em moeda estrangeira, a seção seguinte analisa a questão do spread de "risco soberano" e sua relação com os passivos externos em moeda estrangeira do país (e não do setor público) e discute brevemente também a relação entre esse spread e as notas concedidas pelas agências de rating. $\mathrm{O}$ artigo conclui discutindo de forma sucinta algumas implicações da análise anterior para a discussão recente no Brasil (a partir de 2015) sobre a necessidade e formas do "ajuste fiscal".

PALAVRAS-CHAVE: taxa de juros; finanças funcionais; moeda endógena.

CLASSIFICAÇÃO JEL: E63; E43; B51.

\footnotetext{
1 Os autores agradecem aos comentários e críticas de Carlos Pinkusfeld Bastos, Ricardo Summa, André Lourenço, Fabricio Pitombo, Bráulio Santiago Cerqueira, Miguel Henriques de Carvalho e Flávio Arantes dos Santos, eximindo-os de qualquer responsabilidade sobre os erros remanescentes.

Correspondência para: Franklin Serrano

Contato: franklin@ie.ufrj.br
} 


\title{
HAVE WE REALLY "RUN OUT OF MONEY"? INTEREST RATES AND THE FINANCING OF PUBLIC EXPENDITURES IN A SOVEREIGN CURRENCY COUNTRY
}

\begin{abstract}
This paper discusses the financing of public expenditures and the determination of interest rates on short and long public bonds in a country that has monetary sovereignty. The analysis follows the exogenous interest rate approach that combines the notions of endogenous money of modern monetary theory and of functional finance from Lerner. Focusing particularly in the case of Brazil, the paper begins with the analysis of the operational procedures of government financing and the relationship between Treasury and the Central Bank, the relationship between government financing and the short and long term interest rates on public bonds. As a country (not just the public sector) can indeed go bankrupt in terms of foreign currency, this is followed by the analysis of the "sovereign risk" spread and its relationship with the external liabilities in foreign currency of the country (and not of the public sector) and a brief discussion of the relationship between the spread and the ratings of the international agencies. We conclude by very succinctly pointing out some implications of the above analysis to the recent discussion in Brazil (since 2015) on the need of a major "fiscal adjustment".
\end{abstract}

KEYWORDS: interest rates; functional finance; endogenous money. 


\section{INTRODUÇÃO}

Este trabalho discute como se financiamos gastos públicos e se determinam as taxas de juros sobre os títulos de dívida pública de curto e longo prazo em países de moeda soberana. A análise segue a abordagem da taxa de juros exógena, que sintetiza os resultados comuns da visão da moeda endógena da Modern Monetary Theory e das finanças funcionais de Lerner ${ }^{1}$.

Nosso argumento central é o de que em países de moeda soberana, mesmo naqueles onde o Banco Central é proibido por lei de financiar diretamente o Tesouro, o governo não quebra na dívida pública denominada em sua própria moeda, pois sempre pode se financiar à taxa de juros nominal de curto prazo fixada pelo Banco Central (BC), que, ao fixar essa taxa, compromete-se na prática a comprar qualquer quantidade destes títulos que o setor privado não deseje reter no mercado secundário.

Esse papel de comprador de última instância de títulos públicos do Banco Central não se configura numa monetização da dívida e, uma vez que a taxa de juros fixada pelo Banco Central pode ser bastante alta, não tem porque causar inflação de demanda ou desvalorizações cambiais.

O esclarecimento desta questão teórica que pode, à primeira vista, parecer um tanto abstrata, é, a nosso ver, absolutamente central para a compreensão do debate brasileiro atual sobre o desenvolvimento. Recentemente, a partir de 2015, houve uma reversão de muitas das iniciativas de política econômica para estimular o desenvolvimento adotadas pelo Estado brasileiro. Seja pelo lado do estímulo ao crescimento do mercado interno (transferências sociais, valorização do salário etc.), seja pelo lado da mudança estrutural (políticas industrial e tecnológica) ou social, o motivo central apresentado pelos governos Dilma e Temer têm sido sempre o mesmo: "acabou o dinheiro" Enquanto o país ficar prisioneiro dos interesses que querem nos convencer de que "o dinheiro" realmente "acabou", a retomada do desenvolvimento será impossível, pois qualquer política ativa de desenvolvimento custa "dinheiro".

Focando no caso brasileiro atual, o trabalho começa com a análise dos procedimentos operacionais do financiamento do gasto público e a relação entre o Tesouro e o Banco Central (seção 2), discute as implicações da proposição central mencionada

\footnotetext{
1 Ver Lavoie (2013), Lavoie (2014), Serrano e Summa (2015), Serrano e Summa (2013), Mosler (1995), Wray (2003) e Lerner (1947).

2 Ver declaração do ministro da fazenda Joaquim Levy em Huffpost Brasil (2015) ou da própria ex-presidente Dilma Rousseff, que declarou: "Obviamente, quando se tem um processo de crise, quando se está na fase descendente do ciclo, se perde instrumentos para fazer política anticíclica. Nós viemos fazendo uma política anticíclica em 2011, 2012, 2013 e 2014. Em 2014 nós esgotamos nossa capacidade fiscal de fazer essa política anticíclica" (ROUSSEFF, 2016).
} 
acima para a relação taxas de juros de títulos públicos de curto e longo prazo (seção 3). Como um país (e não apenas o setor público) pode sim quebrar em moeda estrangeira, a seção seguinte (seção 4) analisa a questão do spread de "risco soberano" e sua relação com os passivos externos em moeda estrangeira do país (e não do setor público) e discute brevemente também a relação entre esse spread e as notas concedidas pelas agências de rating. Fechamos o artigo (seção 5) discutindo de forma sucinta algumas implicações da análise anterior para a discussão recente no Brasil (a partir de 2015) sobre a necessidade e formas do "ajuste fiscal".

\section{RELAÇÃO ENTRE TESOURO, BANCO CENTRAL E O SETOR PRIVADO NO FINANCIAMENTO DO GOVERNO}

\subsection{O PAPEL DA CONTA ÚNICA DO TESOURO NO BANCO CENTRAL}

Como se financia na prática o gasto corrente do governo numa economia em que este ao mesmo tempo emite sua própria moeda, mas onde por lei o Tesouro não pode tomar empréstimos do Banco Central e, portanto, não pode se financiar "emitindo moeda"? A garantia de que os pagamentos feitos pelo governo realmente só ocorressem depois da arrecadação tributária ou da receita da venda de títulos públicos criaria enormes problemas práticos e/ou requereria uma fantástica e impossível capacidade de previsão sobre o comportamento da economia e de coordenação entre os diversos órgãos do governo. Felizmente, nada disso é necessário no mundo real, porque neste existe a conta do Tesouro com o Banco Central, que é mantida com um saldo inicial positivo. Assim, na prática, os gastos públicos, quando financiados por meio de uma variação do saldo da conta do Tesouro, mesmo onde o governo legalmente não pode se financiar "através da emissão de moeda", são sim no dia a dia financiados a partir da emissão primária de moeda, isto é, o gasto público de fato injeta moeda nova na economia. E isso não é ilegal, pois o aumento da base monetária correspondente a esses gastos é contabilizado como redução do saldo positivo de ativos do governo com o Banco Central e não um empréstimo deste último ao primeiro. Essa característica operacional básica do setor público tem passado despercebida em muitas análises sobre como o governo financia seus gastos e como de fato são determinadas as taxas de juros de curto e longo prazo que incidem sobre os títulos públicos ${ }^{3}$.

\footnotetext{
Ao contrário dos modelos neoclássicos e pós-keynesianos com base monetária exógena onde há sempre "market clearing" (equilíbrio instantâneo) nos mercados de moeda e títulos.
} 
Como os detalhes institucionais dessa relação básica entre Banco Central e Tesouro variam significativamente para cada país, vamos examinar com mais detalhe o caso brasileiro.

No Brasil, a continuidade dos gastos e transferências do setor público no dia a dia é garantida por um amplo saldo positivo mantido na Conta Única do Tesouro Nacional no Banco Central. Esta envolve a consolidação de todos os saldos em caixa do governo em uma única conta remunerada pelo Banco Central ${ }^{4}$. O saldo da conta única do Tesouro estabelece o tamanho potencial da "folga" que o governo possui no Brasil para pagar suas obrigações sem ferir a legislação vigente ${ }^{5}$.

O Tesouro Nacional se refere à parte do saldo da conta única como um colchão de liquidez preparado para os possíveis resgates dos títulos públicos que estão vencendo por parte do setor privado. Entretanto, em geral, a dívida pública é refinanciada (e não paga ou liquidada), de modo que os recursos da conta única são utilizados para os pagamentos do governo federal em geral ${ }^{6}$. Como se pode ver no Gráfico 1 abaixo, em aproximadamente 15 anos, estas disponibilidades do governo federal no BC oscilaram entre $4 \%$ e $16 \%$ do PIB.

\section{Gráfico 1 - Disponibilidades do governo federal no BC - Conta Única - (\% PIB)}

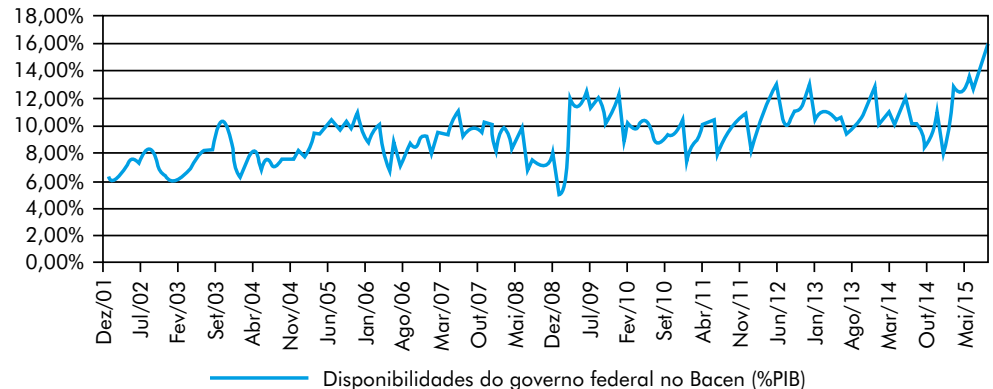

Fonte: BC.

4 Todas as receitas do Tesouro Nacional, com o recebimento de impostos, venda de títulos públicos, receitas de empresas estatais, receitas não recorrentes (etc.) são depositadas na conta única. A Medida Provisória $n^{\circ} 1.789$ de 1998 define, em seu artigo $1^{\circ}$, que "as disponibilidades de caixa da União depositadas no Banco Central do Brasil serão remuneradas, a partir de 18 de janeiro de 1999, pela taxa média aritmética ponderada da rentabilidade intrínseca dos títulos da Dívida Pública Mobiliária Federal interna de emissão do Tesouro Nacional em poder do Banco Central do Brasil".

5 O Artigo 164 da Constituição de 1988 proíbe o financiamento direto do Tesouro pelo Banco Central, isto é, proíbe que o Banco Central compre títulos públicos no mercado primário de títulos. Entretanto, esse mesmo artigo permite que o Banco Central compre e venda títulos públicos no mercado secundário com o objetivo de regular a oferta de moeda ou a taxa de juros. Assim, nada impede que o Tesouro venda um título ao público (dealers primários) e que o Banco Central, a pretexto de política monetária, compre-o.

6 Note que as decisões sobre o volume total de gastos do governo são tomadas com base em projeções de arrecadação e estas podem ou não se tornar realidade. Isso implica que as magnitudes das variações do saldo da conta única do Tesouro no Banco Central não são totalmente antecipáveis pela autoridade fiscal. 
Para termos uma ideia de tamanho relativo, a despesa primária total do governo central em 2015 foi de aproximadamente R\$ 1,2 trilhões (TESOURO NACIONAL, 2016) enquanto as disponibilidades de governo federal no BC (Conta Única) encerraram o ano em R $\$ 880$ bilhões, ou seja, aproximadamente $73 \%$ das despesas primárias totais.

Assim, quando o governo gasta, há um débito no saldo da conta única do Tesouro no Banco Central e um crédito na conta corrente de quem recebeu esse pagamento do governo. Na prática, como o $\mathrm{BC}$ se relaciona com os bancos comerciais, há um crédito na conta de reservas bancárias da instituição de quem recebeu o pagamento do governo. Quando o setor privado paga impostos ao governo, há o movimento contrário, um crédito no saldo da conta única do Tesouro e um débito na conta de reservas bancárias da instituição de quem está pagando impostos ao governo (DE REZENDE, 2009). Sempre que há diferenças entre gastos e as receitas do governo, o saldo da conta única é afetado e isso impacta a base monetária.

Mesmo que, ao final de um ano, o governo gaste exatamente o que arrecada, é operacionalmente impossível coordenar perfeitamente, de modo diário, os gastos públicos e o recebimento dos impostos e receita da venda de títulos. Essa impossibilidade implica que os movimentos do saldo da conta única do Tesouro no Banco Central impactam o mercado de reservas bancárias. O Gráfico 2 abaixo ilustra essa situação em 2014 no Brasil:

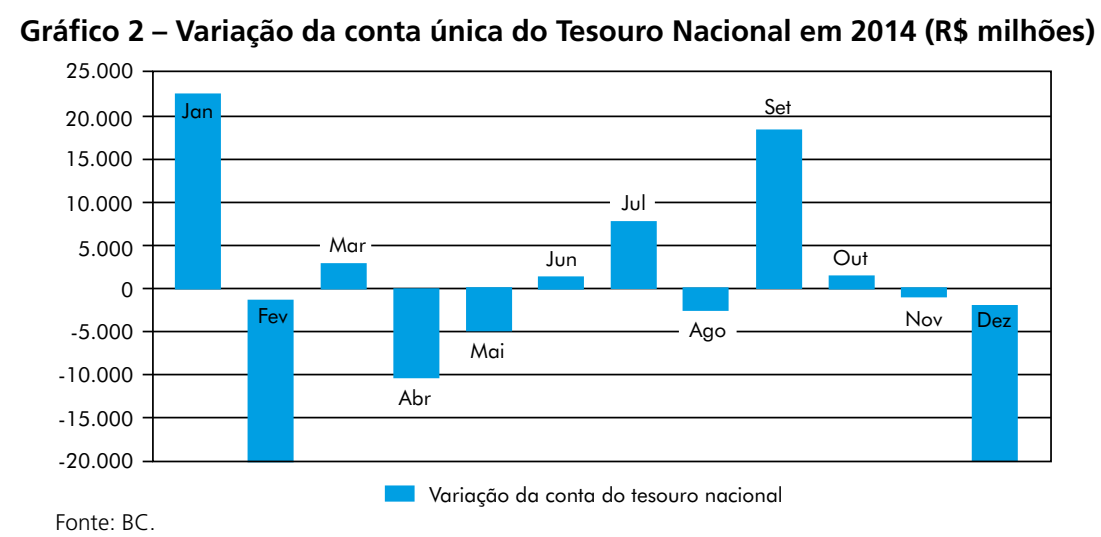

2.2.TAXA DE JUROS, TíTULOS PÚBLICOS E RESERVAS BANCÁRIAS

É pelo mercado de reservas bancárias que o Banco Central se relaciona com os bancos comerciais. As contas de reservas bancárias são contas mantidas pelos bancos co- 
merciais no Banco Central para realizar transações entre si, em nome próprio ou de terceiros, e com o Banco Central. Possuem recursos imediatamente disponíveis para a realização dessas transações. Qualquer transação no sistema bancário passa necessariamente pela conta de reservas bancárias (BC, 1999, p. 87).

A taxa básica de juros diretamente determinada pelo Banco Central - taxa Selic no Brasil - é a taxa de juros que vigora no mercado de reservas bancárias. Assim, em países que emitem sua própria moeda, em geral, o Banco Central determina diretamente uma taxa de juros de curto prazo, a qual se dispõe a comprar ou vender títulos públicos no curto prazo dos bancos privados em qualquer quantidade, de modo a estabilizar o mercado de reservas.

Quando há alterações no mercado de reservas bancárias, o Banco Central é obrigado a agir para fazer com que a taxa de juros no mercado interbancário permaneça próxima à meta de taxa de juros estabelecida pelo Comitê de Política Monetária (Copom).

Se, em um dia, o governo gastou mais do que arrecadou, todo o mais constante, há um excesso de reservas no sistema bancário, e o Banco Central atua vendendo títulos públicos retirando o excesso de reservas ${ }^{7}$. Se em outro dia o governo gasta menos do que arrecada, todo o mais constante, há falta de reservas e o Banco Central atua comprando títulos públicos da carteira dos bancos, fornecendo reservas ao sistema bancário. Essas são as chamadas operações de mercado aberto (sejam operações compromissadas ou definitivas) e, no Brasil, são feitas exclusivamente pelo Banco Central com títulos públicos federais emitidos pelo Tesouro.

Essa atuação diária no mercado de reservas bancárias comprando e vendendo títulos públicos é o principal mecanismo pelo qual o Banco Central operacionaliza a taxa de juros decidida para fins de política monetária evitando oscilações fortes da taxa básica de juros. Segue-se a tendência internacional (BINDSEIL, 2004; CARVALHO et. al., 2007).

No mercado interbancário, a demanda por reservas bancárias no Brasil é condicionada por dois fatores: i) uma fração dos depósitos à vista que os bancos são obrigados a manter no Banco Central, e ii) recursos voluntários que os bancos precisam ter no Banco Central para realizar/liquidar as transações rotineiras. Do lado da oferta de reservas bancárias, o Banco Central tem capacidade ilimitada de ofertar reservas líquidas para o mercado de reservas bancárias como um todo e, portanto, é capaz de determinar a taxa básica de juros. Note que operações entre bancos superavitários e deficitários apenas representam troca de titularidade de reservas bancárias e não criação ou destruição destas (BC, 1999).

Abstraindo das (usualmente pequenas) variações da quantidade de notas e moedas metálicas em poder do público. 
Os movimentos da conta única do Tesouro não são o único motivo que impactam o mercado de reservas bancárias exigindo ações do Banco Central. Aquisições de dólares para a composição das reservas internacionais, movimentos dos depósitos compulsórios e resgates líquidos de títulos da dívida pública federal promovidos pelo Tesouro Nacional também impactam o mercado de reservas bancárias. Para quaisquer desses fatores, o Banco Central não tem escolha. Todo o mais constante, se quiser manter a taxa de juros básica próxima à meta estabelecida, tem de atuar comprando ou vendendo títulos públicos de acordo com a necessidade diária do mercado de reservas bancárias.

Note que a venda de títulos pelo Banco Central acontece porque os bancos em geral não querem ficar com reservas em excesso, pois parte das reservas (parte relacionada aos depósitos à vista) não rende juros e, portanto, qualquer saldo na conta de reservas bancárias além do requerido pelo Banco Central (ou mantido voluntariamente por motivos precaucionais) implica em um custo de oportunidade para os bancos. A taxa de juros que os bancos cobram por essas reservas tenderia a cair a zero (no caso de excesso de reservas) ou a se elevar bruscamente (no caso de falta de reservas), não fosse a atuação do Banco Central (MOSLER, 1995). No caso em que o Banco Central atua comprando títulos públicos da carteira dos bancos, isso acontece porque os bancos necessitam de reservas bancárias para alcançar o mínimo requerido pelo Banco Central e/ou para liquidar transações suas ou de seus clientes.

Atualmente,"o sistema bancário brasileiro convive, estruturalmente, com um excesso de liquidez; com mais recursos do que o necessário para o cumprimento de suas obrigações, inclusive de depósitos compulsórios e as de seus clientes" (BC, 2013). Desse modo, para fazer com que a taxa Selic permaneça próxima à meta decidida pelo Copom, o Banco Central intervém diariamente no mercado de reservas bancárias, sobretudo, por meio de operações compromissadas (repurchase agreements) de curta maturidade, vendendo títulos públicos aos bancos. Nessas operações, o vendedor se compromete a recomprar o título do comprador a um preço acordado e em data específica. $\mathrm{O}$ Banco Central remunera esses títulos à taxa básica, permitindo aos bancos uma alternativa rentável no caso excesso de reservas, de modo que eles não exerçam uma pressão baixista sobre a taxa básica de juros. Atualmente, 95\% do volume negociado das operações compromissadas tem duração de um dia (BC, 2015).

\subsubsection{FINANCIAMENTO DO TESOURO VIA TÍTULOS}

O Tesouro não pode financiar indefinidamente seus deficits com o saldo finito da conta única, sendo esta apenas a maneira mais rápida e funcional de operacionalizar 
os pagamentos do governo no dia a dia. Quando o Tesouro espera que haja um deficit nas contas públicas, ele é então obrigado a se programar para financiar o deficit com a emissão de títulos no mercado primário onde são oferecidos por meio de leilões aos dealers $^{8}$ no mercado primário de títulos. Uma vez vendidos títulos públicos para os dealers nesse mercado, o dinheiro reabastece a conta única do Tesouro no Banco Central. No mercado primário brasileiro, o Banco Central é constitucionalmente proibido de comprar tais títulos.

Há diversos tipos de títulos públicos, que basicamente variam de acordo com o rendimento e prazo. O Tesouro faz a sua estratégia visando minimizar o rendimento pago aos detentores dos títulos e de acordo com as suas prioridades sobre a evolução do perfil da dívida pública. Os dealers também têm sua estratégia visando a maiores taxas de juros.

Os dealers fazem propostas nos leilões e elas podem ou não coincidir com as propostas esperadas pelo Tesouro no financiamento do deficit do governo. A existência do saldo positivo da conta única dá certo poder de barganha ao governo, mesmo no mercado primário, pois ele pode se recusar a vender seus títulos às taxas de juros que o mercado deseje, mas que o governo considere indesejáveis, e se financiar, ainda que temporariamente, por emissão primária de moeda correspondente à redução dos seus ativos no Banco Central. Dessa forma não há necessidade de que o governo aceite sempre qualquer taxa de juros à qual o mercado deseje financiar seus títulos naquele $\operatorname{dia}^{9}$.

Por outro lado, os dealers também podem simplesmente se negar a comprar novos títulos emitidos pelo Tesouro no mercado primário, assim como podem se negar a rolar a dívida (não refinanciando os títulos públicos que estão vencendo). O que acontece nessas situações?

Quando o Tesouro não consegue vender novos títulos no mercado primário à taxa de juros desejada (para financiar um deficit) ou quando os títulos que estão vencendo não são refinanciados (há resgate líquido de títulos), o efeito é o mesmo. O Tesouro paga ao setor privado utilizando recursos da conta única e há uma variação negativa do saldo desta. Nesse caso, o mercado de reservas bancárias, todo o mais constante, é impactado (ficando com excessos de reservas bancárias), e o Banco Central tem de

8 Digna de nota, atualmente, a Caixa Econômica Federal, um banco público, é um dealer no mercado primário brasileiro.

9 Ao contrário do que postulam as teorias neoclássicas e pós-keynesianas de base monetária portfólio exógena (nota 2 acima), que pressupõem "market clearing" instantâneo no mercado de títulos. Assim, tanto a folga que provém da existência da Conta Única do Tesouro quanto a possível atitude cooperativa de "dealers", que são do próprio setor público, como a Caixa Econômica Federal, reforça muito o poder de barganha do Tesouro no curto prazo no próprio mercado primário. 
operar vendendo títulos públicos (retirando esse excesso de reservas) para atingir a sua meta de taxa de juros. É uma atuação passiva do Banco Central (BC, 2013).

A venda de títulos públicos de longo prazo pelo Tesouro no mercado primário, além de se dar por necessidades institucionais, ajuda o Banco Central na administração da meta da taxa de juros. O Banco Central realiza as operações de mercado aberto com títulos do Tesouro, que é o único emissor de títulos públicos no Brasil desde 2002. Note que, do ponto de vista do tamanho da dívida pública em poder do público ${ }^{10}$, não há diferença se o Tesouro consegue ou não vender títulos no mercado primário. No caso de deficit (superavit) do governo não equacionado no mercado primário, as operações de mercado aberto do Banco Central implicam em expansão (contração) da dívida pública em poder do público.

De outro modo, quando o Tesouro emite títulos acima da sua necessidade de financiamento, todo mais constante, existe como contrapartida a redução no volume de operações compromissadas de responsabilidade do Banco Central. Essas operações se resumem à troca, entre duas instituições governamentais, de seus passivos junto ao público. Essa troca não altera os estoques da dívida líquida do setor público nem da dívida bruta do governo geral (TESOURO NACIONAL, 2015).

Desse modo, fica mais fácil entender que em economias nas quais o Estado emite a sua própria moeda e nas quais o Banco Central tem poder ilimitado para atingir a sua meta de taxa de juros, a dívida pública pode ser vista como uma conta da manutenção de taxas de juros reais em níveis positivos (LERNER, 1951).

Vejamos o que implica essa forma de atuação do Banco Central no caso hipotético em que os agentes do setor privado procuram vender massivamente os títulos públicos em carteira. Vamos supor, por exemplo, que o Banco Central nunca compre títulos públicos longos e que por algum motivo o mercado também não queira comprar esses títulos com prazo mais longo. Será que nesse caso não haveria um perigo de o governo não conseguir financiar sua dívida pública e, portanto, haveria um risco de default do setor público pela recusa do mercado de reter títulos públicos de prazo longo? A resposta a essa pergunta é não. Em qualquer país que emita sua própria moeda e no qual o Banco Central esteja disposto a comprar ou vender qualquer quantidade de títulos públicos de curto prazo para atingir sua meta de juros curtos, se o governo não conseguir se financiar com títulos longos, sempre pode e vai automaticamente se financiar com esses títulos públicos curtos a partir da atuação do Banco Central no mercado secundário. No final, ocorre apenas uma troca de dívida pública longa por curta nas

10 Para efeito do grau de endividamento, os indicadores de Dívida Líquida do Setor Público e Dívida Bruta do Governo Geral incluem apenas as operações compromissadas do BC e não os títulos do BC em sua própria carteira. 
mãos do setor privado ${ }^{11}$. Não há perigo algum de o mercado forçar o governo a um default da dívida interna. O default só pode ocorrer por motivos políticos e jamais por imposição do mercado.

O Banco Central desses países, ao fixar a taxa de curto prazo a partir da compra e venda de títulos públicos de curto prazo para os bancos, torna-se indiretamente tanto um emprestador de última instância do governo como também um garantidor de preço mínimo para os títulos públicos, cumprindo assim o importante papel de market maker, ou comprador de última instância para os títulos públicos. É esse poder ilimitado do Banco Central que garante a estabilização da taxa de juros curta dos títulos públicos no patamar desejado pelo Banco Central mesmo em situações nas quais o mercado não deseja financiar o setor público em prazos mais longos, como historicamente tem sido o caso em diversos países em desenvolvimento, como, por exemplo, o Brasil.

Segundo a Constituição brasileira, o Tesouro poderia apenas renovar os títulos em carteira do Banco Central. Entretanto, o forte acúmulo de reservas internacionais ao longo dos anos 2000, que acaba por implicar em operações compensatórias do Banco Central (venda de títulos públicos nas operações de mercado aberto), fez reduzir o estoque de títulos disponíveis em poder do Banco Central para a política monetária. Para resolver essa situação, foi promulgada uma nova lei em 2008 (Lei n. 11.803/2008) permitindo que o Tesouro emita títulos diretamente ao Banco Central, de modo a assegurar que este tenha uma carteira de títulos públicos em dimensão adequada à execução da política monetária (LEISTER e MEDEIROS, 2012).

Assim, temos assegurado em lei, no caso brasileiro, o poder ilimitado do Banco Central para atuar como estamos descrevendo. Em dezembro de 2015, o estoque de títulos utilizados pelo Banco Central nas operações compromissadas estava em $\mathrm{R} \$ 913$ bilhões, respondendo por mais de $20 \%$ do volume de dívida pública (BC). Assim, o risco zero de falência da dívida pública não depende de o Banco Central comprar títulos públicos diretamente do Tesouro no mercado primário. Basta que o Banco Central opere normalmente no mercado secundário comprando e vendendo títulos públicos

11 Ao atuar apenas no segmento de títulos públicos curtos, o Banco Central não controla o perfil da dívida pública. Esse perfil depende fundamentalmente das expectativas do mercado de mudanças futuras na taxa de juros (no caso dos títulos pré-fixados), da taxa de câmbio (quando os títulos públicos em moeda local são indexados às variações do dólar) ou da inflação (para títulos indexados a índices de inflação). As variações no perfil da dívida pública podem afetar seu custo médio. Por exemplo, se antes de uma grande desvalorização cambial o mercado comprou grande quantidade de títulos indexados ao dólar, o custo aumenta. Se o mercado antecipa corretamente uma taxa básica muito mais baixa no futuro e compra grandes quantidades de títulos longos, agora o custo da dívida pública cairá bem mais lentamente do que as taxas de juros. Mas isso não muda o fato de que o governo não vai quebrar se o Banco Central continua fixando a taxa básica de juros. Ver Santiago (2012). 
para os bancos. Vemos assim que o risco de default da dívida pública denominada na moeda de um país soberano é zero, mesmo quando o Banco Central é proibido por lei de emprestar diretamente ao Tesouro, como é o caso dos EUA, do Brasil, do Reino Unido e de dezenas de países avançados e em desenvolvimento (as duas notáveis exceções a essa regra são atualmente o Canadá e o Japão, que permitem que o Banco Central empreste diretamente ao Tesouro) (JÁCOME et. al., 2012)

\subsection{SENHORIAGEM}

Essa proibição de o Banco Central comprar títulos do governo diretamente no mercado primário tem levado muitos analistas a pensar que nesses países o deficit público nunca é financiado pela emissão de moeda. Mas, em qualquer economia monetária, algum ganho de senhoriagem é simplesmente inevitável. Os ganhos totais de senhoriagem para o emissor de uma moeda medido adequadamente com total consistência entre fluxos e estoques são necessariamente iguais ao aumento real do estoque da base monetária. Essa variável tem dois componentes: o valor real do fluxo de novas emissões da base num dado período mais qualquer perda do valor real do estoque anteriormente existente devido à inflação que ocorreu ao longo desse período (que é chamado imposto inflacionário), independentemente de qual foi a causa dessa inflação. A base monetária é um passivo do setor público que paga juro nominal zero (uma taxa de juros real negativa, o imposto inflacionário, se a taxa de inflação for positiva). Os ganhos reais vão para o Estado, que emite tal moeda, e no Brasil são repassados do Banco Central para o Tesouro.

Portanto, toda vez que o setor privado de uma economia (inclusive os bancos) quer e consegue usar um montante real maior de base monetária (que os ortodoxos chamariam de aumento na demanda por base monetária), haverá ganhos de senhoriagem para o emissor dessa moeda. Por conta da identidade contábil do orçamento do setor público consolidado, para um dado deficit fiscal em termos reais acima da linha necessariamente deve corresponder um aumento líquido nas emissões reais de dívida pública e/ou base monetária abaixo da linha. A implicação é de que, mesmo supondo que não há inflação e, portanto, o imposto inflacionário é zero, em qualquer economia em que a base monetária em termos reais está aumentando a uma dada taxa de juros, uma parte do deficit fiscal está necessariamente sendo financiada por emissão monetária.

Nada disso é incompatível com o Banco Central ser proibido de financiar o Tesouro diretamente por compra de títulos no mercado primário. Os bancos centrais em geral não são proibidos de comprar títulos públicos no mercado secundário. Toda vez 
que o Banco Central compra um título público porque, a uma dada taxa de juros escolhida pelo próprio Banco Central, o setor privado consolidado (incluindo os bancos) quer reter mais moeda (base monetária), uma parte do deficit está sendo financiada por emissão monetária. O Banco Central pode escolher e escolhe qual a taxa de juros quer fixar, mas é o setor privado que escolhe a composição entre nova moeda e novos títulos que quer acrescentar a seu portfólio.

A única maneira pela qual o Banco Central poderia realmente se recusar totalmente a financiar deficit seria se o Banco Central não comprasse títulos públicos no mercado secundário e deixasse a taxa de juros endogenamente equilibrar a oferta e demanda de títulos públicos. Nesse caso extremo, no entanto, haveria dois problemas. Primeiro, o Banco Central perderia o controle da taxa de juros básica da economia, o que seria desastroso e provavelmente levaria imediatamente a uma crise bancária e financeira. Em segundo lugar, o Banco Central estaria sempre se recusando a expandir as reservas bancárias e as notas e moedas em circulação, o que seria ainda mais desastroso, pois inviabilizaria o sistema de pagamentos da economia. Felizmente, nenhum país onde a lei proíbe que o Banco Central financie deficit públicos diretamente faz isso, e todos esses bancos centrais financiam parte do deficit fiscal e transferem seus ganhos de senhoriagem ao Tesouro por meio do seu procedimento usual de fixação da taxa básica de juros, comprando títulos públicos no mercado secundário quando o setor privado deseja mais dinheiro e vendendo quando o setor privado deseja menos dinheiro à taxa de juros escolhida pelo Banco Central. Assim, todos os bancos centrais que controlam a taxa básica de juros, além de não deixarem o governo "quebrar", também financiam uma parte do deficit fiscal indiretamente emitindo moeda.

\section{A RELAÇÃO ENTRE TAXAS DE JUROS DE CURTO E LONGO PRAZO DOS TÍTULOS PÚBLICOS}

Como vimos, em países que emitem sua própria moeda, em geral o Banco Central determina diretamente uma taxa de juros de curto prazo à qual o banco se dispõe a comprar (ou vender) títulos públicos de curto prazo dos bancos privados. Essa taxa é usada para regular e estabilizar a taxa de juros no mercado interbancário privado. Como isso torna fácil para o mercado obter grande quantidade de fundos a essa taxa, no mercado secundário a taxa de juros da dívida pública de prazos mais longos, quando denominada e paga nessa mesma moeda, depende basicamente da taxa básica de juros fixada pelo Banco Central e das expectativas do mercado quanto ao curso futuro destas. Para títulos públicos de prazos longos, há muito mais incerteza sobre as futuras mudan- 
ças na taxa básica, e em geral os investidores também requerem um pequeno prêmio adicional pelo risco de perda de capital se estiverem errados (especialmente quando a taxa nominal esta muito baixa - próxima de zero, por exemplo). Isso torna o nível e a trajetória da taxa de juros da dívida pública mais longa menos colados na taxa básica de juros corrente, mas, mesmo assim, ao longo do tempo a concorrência e as oportunidades de arbitragem fazem com que a tendência da taxa de juros de longo prazo da dívida pública siga necessariamente a tendência da taxa básica de curto prazo. E a taxa de juros da dívida pública longa dá a base de risco zero para que os bancos privados formem suas taxas de juros para prazos semelhantes, adicionando seu spread que reflete, além de impostos, as condições de concorrência (ou falta de) no setor financeiro e o risco percebido dos diversos tipos de tomadores privados.

No Brasil, a taxa básica de juros é importante para definir o custo do financiamento do setor público diretamente por causa das operações compromissadas do Banco Central, das Letras Financeiras do Tesouro (LFT), títulos de longo prazo emitidos pelo Tesouro Nacional indexados diretamente à taxa Selic, e indiretamente porque a taxa básica influencia fortemente as taxas de juros que incidem sobre os títulos de longo prazo pré-fixados.

Do nosso argumento decorre que o nível e a trajetória da taxa de juros da dívida pública mais longa dependem da evolução da taxa básica de juros. Assim, em face de elevações da taxa de juros básica, o Tesouro Nacional acaba por seguir este movimento aumentando as taxas sobre as novas emissões de títulos de longo prazo, de modo a preservar uma rentabilidade adicional para preservar a demanda por esses títulos. $\mathrm{O}$ Gráfico 3 a seguir mostra a evolução da taxa de juros básica (Selic) e a taxa de juros de longo prazo pré-fixada, que incide sobre as Letras do Tesouro Nacional (LTN):

Gráfico 3 - Taxa de juros média: curto (Selic) e longo (LTN)

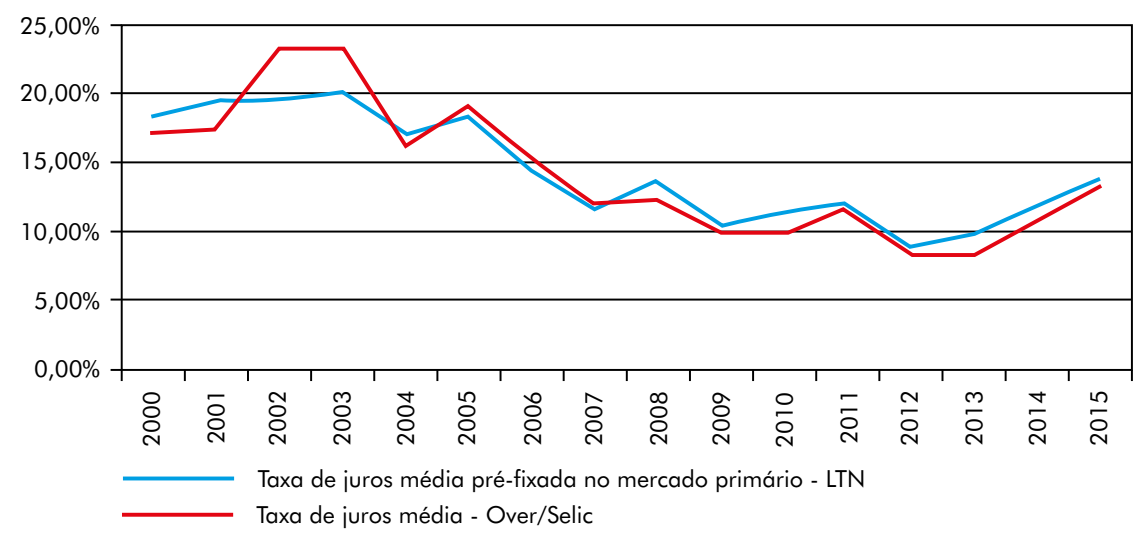

Fonte: Elaboração própria com base em dados do Ipeadata e Tesouro Nacional. 
Note no gráfico acima que entre os anos de 2002 e 2003, anos de elevação das duas taxas de juros, há certo descolamento entre a taxa básica de curto e a taxa de longo, esta ficando menor. Isso acontece, porque em geral momentos de fuga de capitais geralmente são seguidos de forte elevação da taxa básica de juros pelo Banco Central, que procura evitar a desvalorização cambial e o seu impacto sobre a inflação e o mercado espera isso. O Tesouro pode, por sua vez, dada a folga com que trabalha para o financiamento do deficit público (discutida na seção 2 acima), esperar a normalização das condições do mercado de capitais para voltar a oferecer títulos de longo prazo a taxas de juros menores (TESOURO NACIONAL, 2015, p. 13).

De maneira geral, não há problemas com a liquidez dos títulos de longo prazo nos mercados secundários, no sentido de implicar em perdas significativas para os detentores desses títulos que queiram negociar nos mercados secundários (exceto em momentos de elevada instabilidade, como aponta o Gráfico 4 a seguir).

Ao longo do tempo, a concorrência e as oportunidades de ganhos especulativos fazem com que a tendência da taxa de juros de longo prazo da dívida pública siga bem de perto a tendência da taxa básica de curto estabelecida pelo Banco Central para fins de política monetária, como aponta o Gráfico 4 a seguir:

\section{Gráfico 4 - Taxa longa e Taxa Selic - Mercado Secundário}

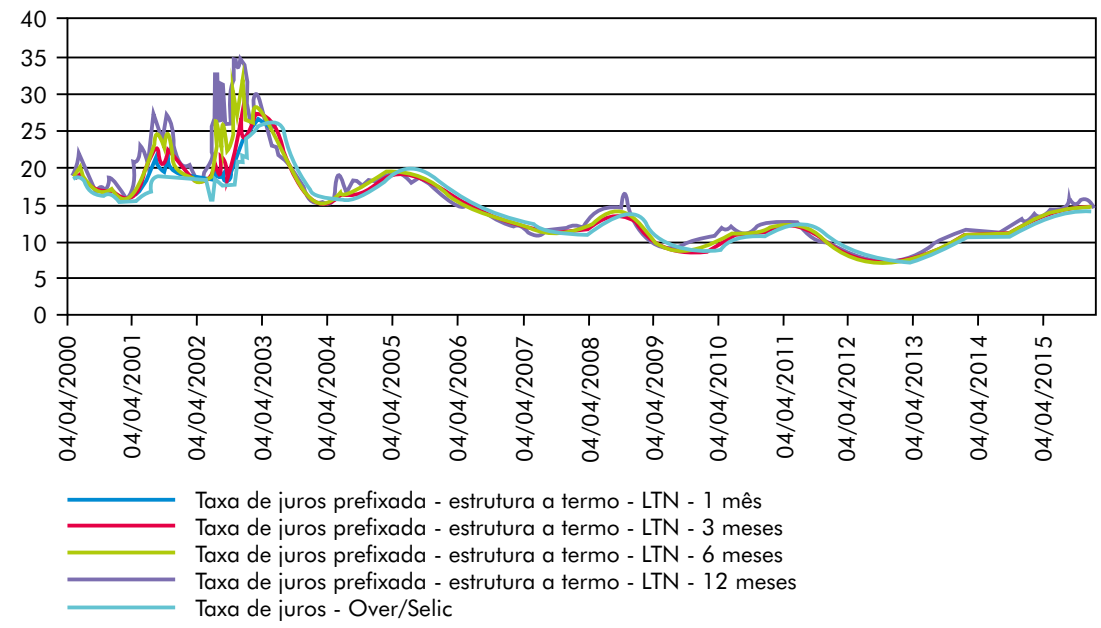

Fonte: Ipeadata.

A demanda pelos títulos de longo varia de acordo com a expectativa do mercado sobre o curso futuro da taxa de juros de curto prazo e, por isso, em momentos de elevada instabilidade macroeconômica, o preço dos títulos de longo pode sofrer alguma variação errática, mas esta não é a regra, como o Gráfico 4 logo deixa evidente. 
Note que a relação entre a taxa básica e as taxas mais longas dos títulos públicos no Brasil é tão forte que deixa claro que variáveis fiscais como o tamanho da dívida pública bruta ou líquida ou o deficit público é que são afetados pelas taxas de juros curtas e longas, e não o oposto. Mesmo a situação das contas externas e a evolução esperada da taxa de câmbio só afetam as taxas de juros de longo prazo na extensão em que afetarem as decisões correntes e as expectativas do mercado quanto às decisões futuras do Banco Central sobre a taxa de juros básica (ver seção 4 a seguir).

Aqui vale a pena, devido à inexistência de títulos públicos de prazo muito longo no Brasil, olharmos um pouco o caso americano. Nos EUA, essa tendência de a taxa longa dos títulos públicos (os “treasuries" de 10 anos, por exemplo) seguir a tendência da taxa curta do Banco Central é bastante clara, como aponta o Gráfico 5 a seguir:

Gráfico 5 - EUA: Taxa de juros de curto e longo prazo (\% a.a)

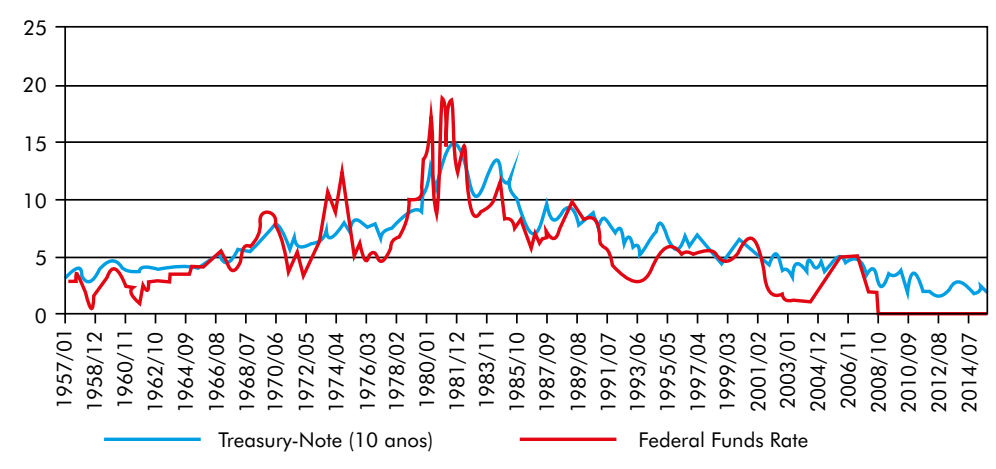

Fonte: Ipeadata.

Em particular se nota que, em períodos imediatamente anteriores a uma recessão, nos quais o mercado sabe que o Banco Central americano costuma reduzir bastante a taxa de curto prazo, mas por um tempo relativamente limitado em relação ao prazo do título, é comum a taxa longa cair antes da taxa curta, a tal ponto que é comum a ocorrência, nesses períodos, de uma curva de rendimento (yield) invertida, na qual a taxa de curto prazo é mais alta do que a de longo (que incorpora a expectativa de queda da taxa de curto).

Isso ocorre por conta tanto do mandato dual do FED se preocupar não só com a inflação como também com o desemprego, e também pela ausência de preocupação deste com problemas ligados ao câmbio e balança de pagamentos, já que o mundo continua no padrão dólar flexível.

Essa tendência de as taxas de títulos públicos bem longos seguirem a política monetária nos EUA ilustra também o que não determina a taxa de juros da dívida pública americana. $\mathrm{O}$ tamanho da dívida interna americana é uma das coisas que não deter- 
mina a taxa de juros. Não há simplesmente nenhuma relação causal sistemática entre tamanho da dívida interna (que tem crescido continuamente em relação ao PIB) e a taxa de juros da dívida pública, que segue a tendência dada pela evolução da taxa básica de juros do Banco Central. Também não há relação dos juros de longo prazo com o tamanho do deficit público.

Outro fator que não determina a taxa de juros longa da dívida pública americana são as avaliações ou ratings das agências privadas de risco. Em setembro de 2011, a agência Standard \& Poor's rebaixou a dívida interna americana e tanto a dívida interna continuou crescendo quanto a taxa de juros continuou sua trajetória de forte queda.

É importante ressaltar que apenas fatores que afetem as decisões do Banco Central quanto a que nível este vai fixar a taxa básica de juros poderão afetar substancialmente a taxa de juros da dívida pública americana. Por exemplo, a conhecida tese de que seria a China que, como grande compradora de títulos públicos americanos, em última instância determina a taxa de juros destes, é falha por não explicar porque o governo americano não responderia a uma venda de títulos pelos chineses simplesmente deixando a taxa de câmbio desvalorizar em vez de subir os juros de curto prazo para evitar tal desvalorização. No caso da relação entre os Estados Unidos e a China, é evidente que de um lado os EUA não se preocupam com uma desvalorização cambial acentuada, poisa desvalorização do câmbio tem muito pouco efeito sobre a inflação nos EUA (que é um dos objetivos do Banco Central americano), e, ainda por cima, reduz o valor dos passivos externos americanos. Por outro lado, não interessa à própria China a valorização cambial do yuan, pois não apenas isso poderia levar a perda de parcelas de mercado nas exportações mundiais, mas, principalmente, porque seus ativos externos em dólar perderiam o valor. A China, sendo credora líquida em dólares, compra títulos públicos americanos para evitar a valorização cambial, e não é a causa dos juros baixos nos EUA. A causa dos juros baixos é a política monetária americana (e o mesmo pode ser dito sobre a taxa de juros da dívida pública longa dos demais países que emitem suas próprias moedas $)^{12}$.

A experiência americana e internacional em geral também mostra que as avaliações das agências de rating também não têm capacidade de impor "disciplina" fiscal aos países que emitem sua própria moeda,ou ainda que o rebaixamento das notas atribuídas pelas agências tenha algum efeito de elevar persistentemente a taxa de juros da dívida pública de longo prazo desses países. As medidas de política econômica em resposta à crise de 2008, seja pelos deficits fiscais primários, seja pela ajuda dos bancos centrais e tesouro nacionais às instituições financeiras para reciclarem suas estruturas ${ }^{12}$ Ver Serrano e Braga (2006) para a crítica da relação entre deficit fiscal e juros nos EUA, e Serrano (2008)
para a crítica à ideia de que a taxa de juros americana depende da China. 
patrimoniais, têm aumentado rapidamente as relações dívida/PIB em diversos países do mundo.

Em setembro de 2011, a agência Standard \& Poor's rebaixou a dívida interna americana, e tanto a dívida interna continuou crescendo quanto a taxa de juros continuou sua trajetória de queda. O Japão também já teve sua dívida rebaixada em dezembro de 2001 pela agência Moody's, e mais recentemente, em maio de 2012, pela agência Fitch. Em ambos os casos o argumento central das agências era o alto risco da dívida interna em yen ser tão elevada. Em ambos os casos, o efeito do rebaixamento sobre a taxa de juros da dívida pública foi o mesmo: nenhum.

Note que nada impede que alguns agentes vendam títulos públicos após e até por causa do rebaixamento. Em alguns casos, investidores institucionais são forçados por lei a fazer isso, pois existem regras sobre o rating mínimo aceitável em suas carteiras. Mas, mesmo assim, em geral não é de se esperar que o rebaixamento afete a taxa de juros longa da dívida interna de forma persistente e que afete de alguma maneira as taxas curtas. Quando alguns investidores vendem os títulos públicos rebaixados, de fato seu preço cai e sua taxa de retorno (yield) sobe. Mas se a taxa básica de juros do Banco Central não mudou, a taxa de retorno maior oferece uma oportunidade de ganho fácil, dada a facilidade de captar recursos à taxa básica ou próxima dela e comprar o título longo de rendimento mais alto. Em geral, essas oportunidades de lucro extra são aproveitadas rapidamente; o movimento de compra faz o preço do título subir e sua taxa de retorno voltar ao patamar anterior. No limite, se o Banco Central achar que esse processo está lento e desejar reduzir os juros longos, basta começar a comprar diretamente os títulos de prazos mais longos vendidos no mercado secundário, fazer subir seus preços e baixar seu rendimento (como alguns países desenvolvidos têm feito parcialmente nas políticas chamadas de quantitative easing).

As implicações do fato de o governo não quebrar em sua própria moeda e sempre ter financiamento disponível no mercado secundário à taxa de juros fixada pelo Banco Central da forma descrita acima são pouco compreendidas. Em geral se pensa que o governo só não quebraria se houvesse a alternativa de deixar a taxa de juros cair a zero e "monetizar" a dívida. Já vimos que isso de forma alguma é necessário, pois a taxa fixada pelo Banco Central pode ser elevada o suficiente para não causar nenhuma fuga dos títulos públicos nem da moeda doméstica para moeda estrangeira ou qualquer outro ativo. No entanto, sabe-se que um deficit público permanente, mesmo que pequeno em relação ao produto, pode implicar uma razão dívida PIB que cresce continuamente se a taxa de juros líquida de impostos paga nesses títulos for maior do que a taxa de crescimento da receita fiscal (no caso de uma carga tributária constante ou que cresce à mesma taxa que o PIB). Nesse caso, no qual em geral se diz que a dívida pública é “insustentável”, de fato as transferências do governo aos credores internos crescem 
continuamente com o pagamento dos juros da dívida. Isso é algo certamente indesejável do ponto de vista distributivo, e o ideal seria que o governo mantivesse a taxa de juros real menor do que a taxa de crescimento da economia sempre que for possível. Mas quais seriam as consequências macroeconômicas no caso "insustentável"? Aqui existem duas possibilidades, dependendo da hipótese que for feita sobre o comportamento dos agentes privados que recebem os juros. Supondo que a propensão marginal a gastar dos juros recebidos seja praticamente zero, dado que tais agentes em geral são ricos, têm amplo acesso a crédito e seu consumo é basicamente autônomo, a consequência seria basicamente nenhuma. A poupança privada aumentaria na extensão em que a poupança do setor público fosse diminuindo, e a demanda agregada não seria afetada. Mesmo supondo que a propensão a consumir dos que recebem tais transferências seja positiva, não nos parece plausível supor que o efeito disso na demanda agregada seja em geral mais forte do que os impactos negativos dos juros elevados sobre o consumo e o investimento residencial a ponto de o efeito líquido expansionista sobre a demanda agregada ser significativo. Mas o que nos interessa aqui é que, mesmo no caso implausível em que o aumento do consumo dos detentores da dívida pública expandisse a demanda agregada a ponto de o governo ter de reduzir o ritmo de crescimento dos seus gastos e o tamanho do seu deficit (aumentando impostos), isso não se dará por falta de financiamento, mas apenas para evitar inflação de demanda. E como, nesse caso extremo, por definição, não haveria mais falta de demanda efetiva em relação ao produto potencial da economia, isso não seria um problema, pois de qualquer forma não haveria mais nenhum bom motivo para o governo querer continuar aumentando seus gastos totais e apresentar deficit, dado que o objetivo da política fiscal expansionista a partir da doutrina das "finanças funcionais" nunca foi gerar excesso de demanda agregada crônico de propósito ${ }^{13}$.

\section{O SPREAD, AS NOTAS DAS AGÊNCIAS DE RATING E A TAXA DE JUROS INTERNA NO BRASIL}

É importante ressaltar que o fato de o Banco Central controlar a taxa básica de juros e ter essa forte influência também sobre a taxa de juros de longo prazo dos títulos públicos não significa de forma alguma que a autoridade monetária possa fixar os juros arbitrariamente. Mudanças na taxa de juros podem ter variados efeitos, às vezes contraditórios sobre os objetivos do governo, sobre a distribuição de renda, o nível de 13 Por isso Abba Lerner (1951), especulando sobre esse caso extremo e bastante irrealista, dizia que tal
situação levaria à "morte natural” do deficit e do crescimento da dívida pública. 
atividade, a dívida pública e, em particular, sobre a taxa de câmbio e a conta de capitais da balança de pagamentos. Isso significa que o Banco Central não decide sua política de taxas de juros num vácuo, e sim de acordo com suas prioridades e restrições de política econômica (PIVETTI, 1991).

Particularmente, numa economia com alta mobilidade de fluxos de capital de curto prazo, os graus de liberdade da política monetária se mostram bastante assimétricos (SERRANO e SUMMA, 2013). Mas isso em nada altera o fato de que a taxa de juros básica é exógena no sentido de ser uma variável de política econômica.

Nesse contexto, a principal restrição à política de juros no caso do Brasil atual está relacionada às condições externas. $\mathrm{O}$ país está inserido num sistema monetário e financeiro internacional assimétrico. A taxa de juros com frequência é utilizada para atrair capital estrangeiro, o que implica na criação de um diferencial de juros que condiciona a atuação do Banco Central. Nesse sentido, quando o Banco Central quer evitar desvalorizações cambiais, deve manter os juros acima da soma dos juros externos mais o spread do chamado risco soberano e das expectativas de desvalorização cambial do mercado. Tanto o spread quanto a possibilidade de o Banco Central influenciar as expectativas cambiais são fortemente afetados pela situação estrutural do balanço de pagamentos do país, e em particular pela disponibilidade de reservas internacionais (medidas em relação aos passivos externos de curto prazo em moeda estrangeira).

\subsection{O SPREAD DE RISCO SOBERANO DO BRASIL}

Nesse início de século XXI assistimos ao processo de descolamento da tendência de maior crescimento dos países periféricos em relação aos países centrais. Esse processo foi possibilitado pela melhoria das condições externas que determinam a restrição de balanço de pagamentos da periferia em geral (MEDEIROS, FREITAS e SERRANO, 2015).

A melhoria das condições externas é baseada na política monetária americana (de juros baixos), que condiciona o fluxo de capitais privados para os países periféricos e na melhora dos preços relativos das commodities exportadas por esses países. As altas taxas de crescimento da China e a mudança de gestão da política econômica dos próprios países periféricos, adotando políticas voltadas ao crescimento, e regimes cambiais flexíveis, porém administrados, com forte acúmulo de reservas, também contribuiu para a melhora geral das condições externas da periferia, aumentando também a corrente de comércio entre os países periféricos.

No caso brasileiro recente, o cenário externo particularmente favorável a partir de 2004 em termos de juros externos, fluxos de capitais, crescimento do mercado externo e dos preços das commodities possibilitou a acumulação de um expressivo nível de 
reservas internacionais (atualmente estável em aproximadamente US\$ 370 bilhões). O Gráfico 6 a seguir relaciona o nível mensal de reservas internacionais e o nível mensal do $E m b i+\mathrm{Br}^{14}$ (média mensal feita pela média simples a partir de dados diários), que é uma medida do risco-Brasil utilizada no mercado financeiro internacional.

Gráfico 6 - Brasil: Risco Soberano e Reservas Internacionais

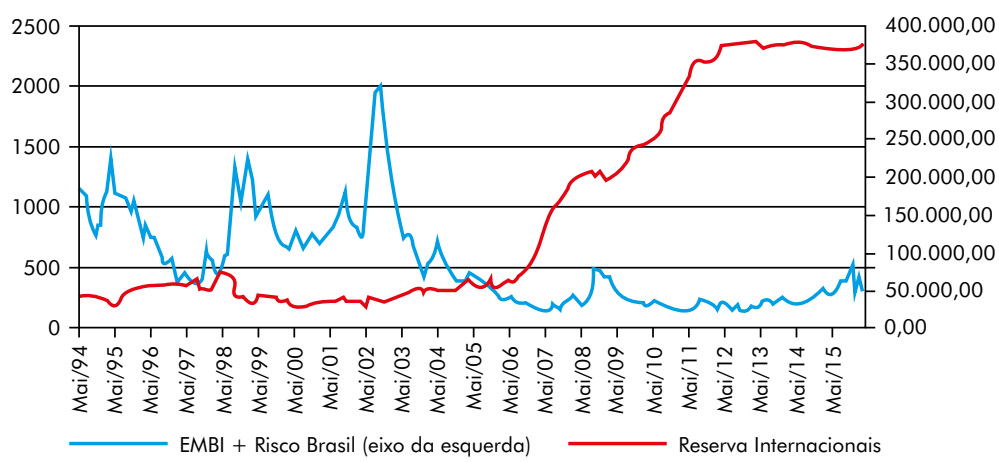

Fonte: Ipeadata.

Sobre o gráfico acima vamos colocar algumas considerações:

i) Note como o baixo nível de reservas internacionais está associado aos maiores níveis e às fortes elevações do risco-país em momentos de crises de cambiais brasileiras e/ou turbulências financeiras internacionais (como, por exemplo, 1995, 1998 e 2002).

ii) De maneira correlata, note que o alto nível de reservas internacionais está associado a um nível bem menor do risco soberano, assim como a uma menor variabilidade dessa medida de risco. Mesmo durante o agravamento da crise externa no último quadrimestre de 2008, o risco soberano não ultrapassou os 500 pontos-base (na média mensal).

iii) Destaca-se que a forte redução do risco soberano acontece até 2006 e, portanto, precedeu o recebimento do chamado "grau de investimento" (abril de 2008) pelas agências de rating internacionais.

14 “O EMBI+Br é um índice que reflete o comportamento de títulos da dívida externa brasileira. A variação do índice entre duas datas permite calcular o retorno de uma carteira composta por esses títulos. O spread do $\mathrm{EMBI}+\mathrm{Br}$ é o valor normalmente utilizado pelos investidores e público em geral como medida do risco soberano do Brasil e corresponde à média ponderada dos prêmios pagos por esses títulos em relação a papéis de prazo equivalente do Tesouro dos Estados Unidos, que são considerados livres de risco. Esse prêmio de risco é chamado no jargão de mercado como spread over Treasury dessa carteira. Basicamente, o mercado usa o EMBI+Br para medir a capacidade de o país honrar os seus compromissos financeiros, ou seja, quanto maior a pontuação do indicador de risco, maior é o risco de crédito do país a que se refere" (BC, 2015, p. 3). 
Não só foram acumuladas reservas internacionais como o endividamento externo brasileiro diminuiu expressivamente no período, melhorando a situação de solvência externa brasileira. O Gráfico 7 a seguir mostra a evolução do Embi+Br, agora com uma média anual feita pela média simples a partir de dados diários, e a evolução anual da razão dívida externa bruta/reservas internacionais (um indicador possível de solvência externa).

\section{Gráfico 7 - Brasil: Solvência Externa e Risco Soberano}

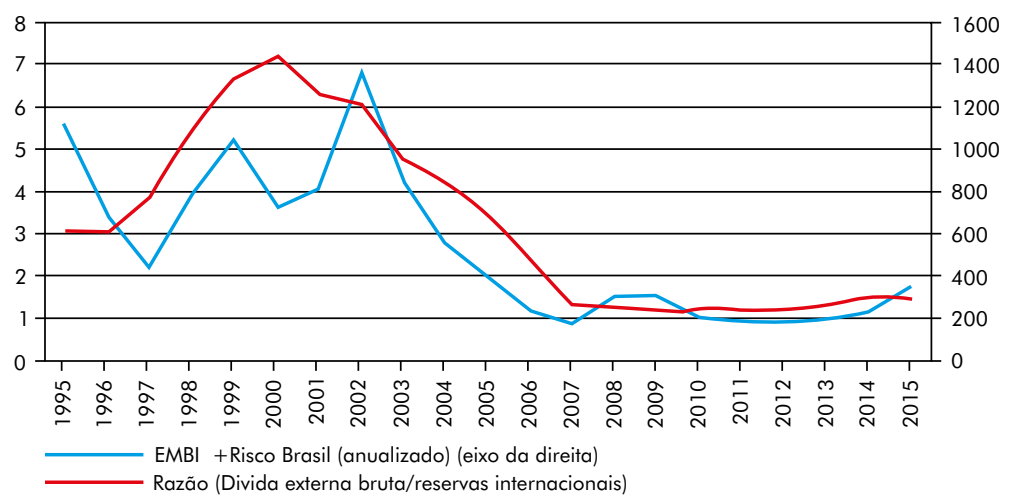

Fonte: Ipeadata.

Além da mudança nas condições internacionais, houve uma melhora estrutural dos indicadores de solvência e liquidez externa do Brasil (SERRANO e SUMMA, 2012), assim como o fato associado apontado por Biancarelli (2015), de que o atual passivo externo acumulado da economia brasileira está majoritariamente denominado em reais, o que transfere boa parte do risco cambial para os investidores externos ${ }^{15}$. Estes fatores parecem explicar bem a tendência de substancial queda do risco soberano do Brasil desde 2003. De fato, a probabilidade de o país ser forçado a interromper

15 "A desvalorização, quando atinge economias com grandes compromissos externos em dólares, piora a situação patrimonial - já que grande parte das receitas é em moeda nacional. Esse descasamento de moedas, fruto do chamado 'pecado original', ou a incapacidade de se endividar externamente na sua própria moeda, se alterou de maneira pronunciada (e pouco comentada) na trajetória brasileira da última década e meia. Fruto de uma participação muito maior de passivos de carteira (ações e títulos de renda fixa) negociados no país e dos volumosos estoques de investimento direto estrangeiro, houve uma 'desdolarização' significativa: ao final de 2014 em torno de $60 \%$ dos passivos totais estavam em real(contra pouco mais de $30 \%$ em 2001). Nos compromissos de carteira, a mudança é ainda maior: $64 \%$ contra apenas $10 \%$ no início do século. A consequência disso é que o risco cambial passou em parte para o 'credor' do Brasil. E que, diante de desvalorizações agudas (como a do fim de 2008 e novamente agora), a situação de vulnerabilidade pelo ângulo dos estoques melhora, e não mais piora. A duração desta mudança positiva (ainda mais se a desvalorização do real for mantida) e a extensão de seus impactos merecem acompanhamento e reflexão. Mas certamente essa é outra das novidades do setor externo brasileiro que diferenciam o momento atual de outros períodos de dificuldades" (BIANCARELLI, 2015, p. 19). 
involuntariamente seus pagamentos em moeda estrangeira caiu dramaticamente em relação a outros períodos históricos. Isso dá margem de manobra para o Banco Central baixar significativamente o nível das taxas básicas de juros do país sem risco de desvalorizações cambiais descontroladas.

\subsection{AS NOTAS DAS AGÊNCIAS DE RATING E O SPREAD DO BRASIL}

No início de 2015, com uma nova equipe econômica, houve uma mudança radical na política econômica,com uma série de medidas recessivas e concentradoras de renda, que tiveram como objetivo declarado reduzir a dívida interna bruta em proporção do PIB supostamente para evitar o rebaixamento das notas do Brasil dadas pelas agências avaliadoras de risco. Tal rebaixamento acabou ocorrendo de qualquer jeito, e a nova política econômica fez com que a economia, já estagnada, entrasse numa recessão profunda, que se estende pelo ano de 2016.

A justificativa oficial, que rapidamente se tornou consensual entre os mais diversos tipos de economistas, inclusive "heterodoxos", era a de que o ajuste fiscal e as políticas de austeridade em geral seriam “impostas" pelas agências de rating internacionais e que as consequências de não se seguir a recomendação das agências seriam drásticas.

A “imposição", parece-nos, teria a seguinte relação de causalidade: se o Brasil não fizer o ajuste fiscal, a relação dívida bruta/PIB se eleva, pioram as notas atribuídas pelas agências, o Brasil perde o grau de investimento, o que provoca a redução dos fluxos de capitais para o Brasil (inclusive IDE) e a elevação do spread (risco soberano) pago internacionalmente pelo Brasil. Poderia haver também uma fuga do capital externo, provocando possivelmente crises cambiais e induzindo a elevações da inflação e consequentemente elevações ainda maiores da taxa de juros e desaceleração econômica etc. Note que a causalidade parte da situação fiscal para as notas das agências de rating, e daí então para aumento do risco soberano, induzindo à elevação da taxa de juros interna com o objetivo de evitar desvalorizações cambiais e/ou fuga de capital.

Para evitar essa catástrofe, o governo brasileiro seria forçado a (re)equilibrar as contas públicas, recompondo o superavit primário suficiente para mostrar uma tendência de redução da relação dívida bruta bruta/PIB. Esse seria o indicador atual mais relevante para as agências de rating, e, por causa disso, para o mercado internacional ${ }^{16}$. Em síntese, as agências de rating teriam um papel central na determinação dos fluxos de capitais, sobre o spread soberano e, assim, sobre a taxa de juros brasileira.

\footnotetext{
${ }^{16}$ Curiosamente, no relatório de rebaixamento da Standard \& Poor's, ver Vernengo (2015), a causa mencionada é o crescimento da dívida líquida e não bruta.
} 
Já vimos acima que na prática as agências de rating não têm efeitos diretos relevantes sobre as taxas de juros longas das dívidas públicas de países que emitem sua própria moeda ${ }^{17}$. Aqui o argumento é que essas agências avaliam a solidez da capacidade de pagamento dos passivos externos em moeda estrangeira do país (privada e pública) a partir da situação da dívida interna do setor público denominada na moeda nacional ${ }^{18}$. Não é difícil ver a falta de lógica desse critério. Isso, aliás, é reconhecido por muitos. No entanto, mesmo assim há um enorme consenso de que qualquer critério, por absurdo que seja, usado por tais agências, deve ser levado em conta, pois o rebaixamento em si, por qualquer que seja o motivo, impactaria fortemente o spread externo (risco-país).

É interessante notar que no mundo real as agências de rating e seus critérios (anunciados) arbitrários não têm o monopólio dos fluxos internacionais de capital. Além disso, essas agências tendem a ser forçadas pela concorrência e pressão de seus clientes, mais cedo ou mais tarde, a melhorar as notas de países onde de fato está sendo mais lucrativo aplicar capital externo (e rebaixar no caso oposto). Nesse caso, teríamos a relação oposta: a variação do spread de risco é que explicaria a tendência das notas das agências.

Os fatos parecem, à primeira vista, confirmar que as mudanças no spread precedem as mudanças nas notas no caso do Brasil. No ano de 2003, enquanto a média das notas do Brasil atribuídas pelas agências de rating basicamente se mantinha (apenas a Fitch melhora a nota brasileira), o risco-Brasil declinava fortemente, assim como os fluxos de capitais voltavam para o Brasil valorizando a moeda brasileira. $\mathrm{O}$ risco soberano brasileiro em 2002 chegou a ultrapassar a barreira dos 2000 pontos-base. Em 2003, esse índice encerra o ano em 463 pontos-base. Em 2004, as notas atribuídas ao Brasil pelas três agências de rating voltariam a melhorar, seguindo a melhora dos indicadores externos da economia brasileira.

Conforme vimos acima, a forte redução do risco-Brasil acontece até 2006, quando o Brasil ainda era considerado "especulativo" pelas agências de rating internacionais e, portanto, precedeu o recebimento do chamado "grau de investimento", que aconteceu só em abril de 2008.

17 Uma publicação da própria Standard \& Poor's, Sheard (2013), sobre a atual política monetária americana trata a determinação da taxa básica de juros e tece considerações sobre a oferta de moeda de maneira totalmente alinhada com a tradição da abordagem da taxa de juros exógena, situação em que é impossível o governo quebrar em sua própria moeda.

${ }_{18}$ É importante ressaltar que o spread de risco soberano se aplica diretamente ao risco de default de títulos públicos em moeda estrangeira. O chamado risco-país é mais amplo e mediria o risco dos devedores públicos e privados do país em moeda estrangeira. Como o setor público é reconhecido como sendo o devedor de menor risco, o risco soberano fixa um piso para o risco-país que inclui títulos de dívidas privadas (YOSHIMOTO, 2004). 
Para avaliar empiricamente com mais clareza qual das duas interpretações seria mais razoável no caso do Brasil, criamos um índice simples atribuindo números às diferentes notas das agências de rating ${ }^{19}$. Quanto menor o número desse índice, melhor a nota da agência. O Gráfico 8 a seguir mostra a evolução desse índice e do risco soberano.

\section{Gráfico 8 - Evolução do índice de rating e do risco soberano brasileiro}

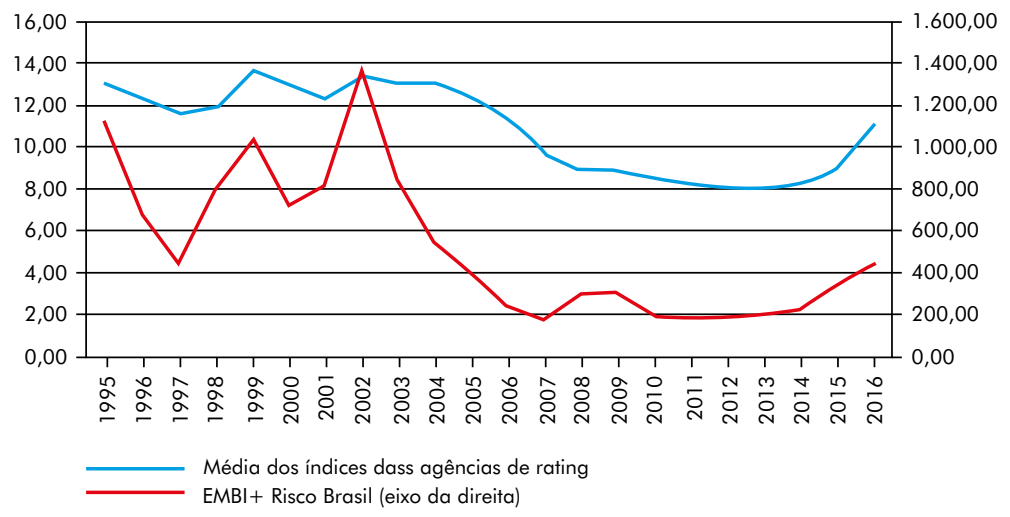

Fonte: Elaboração própria com base em dados de Ipeadata e Agências de risco.

Não é surpreendente que o Gráfico 8 mostre que, em geral, ao contrário da visão consensual, é o spread de risco soberano que lidera a tendência das duas séries com a média das notas de avaliação de risco seguindo a evolução do spread de risco soberano. Este último depende, como vimos, da situação internacional e das contas externas do país, e nada tem a ver com a dívida pública na moeda local.

Por fim, note que, desde o início de 2015, com o absoluto fracasso da política econômica em alcançar seu objetivo declarado por meio de um forte ajuste fiscal, as agências de rating pioraram uma a uma as notas atribuídas ao Brasil. No fim de 2015, o Brasil perdeu o "grau de investimento", e o risco soberano brasileiro permanece atualmente em níveis historicamente baixos, e a situação externa permanece tranquila, não há fuga massiva de capitais. Nesse cenário, a mais recente revisão da meta fiscal brasileira, em maio de 2016, com aprovação de um expressivo deficit primário, é um reflexo singelo de que os constrangimentos ao deficit público em países de moeda soberana são de natureza política e nada tem a ver com uma suposta fragilidade do setor público na questão do financiamento.

${ }^{19} \mathrm{O}$ índice é simples e consistiu em numerar todas as possíveis notas das agências na seguinte ordem: o índice zero (número zero) é dado ao melhor rating possível (nota AAA), o número 2 ao segundo melhor rating possível etc. O número 21 seria atribuído ao pior índice de rating (nota $\mathrm{D}$ ). Assim, quanto menor o índice de rating, melhor a nota da agência aos títulos de dívida brasileiros (moeda nacional). O histórico de notas utilizado pode ser acessado em: $<$ http://sisweb.tesouro.gov.br/apex/f?p=2810:2 >. 


\section{OBSERVAÇÕES FINAIS}

Como vimos, o governo não pode ser forçado a um default nos títulos da sua dívida interna pelo mercado em uma economia como a brasileira, na qual o Banco Central fixa a taxa básica de juros atuando no mercado secundário (reservas bancárias). Além disso, vimos que a situação da balança de pagamentos do Brasil está totalmente sob controle. Pela análise anterior fica claro então que a necessidade técnica de a economia brasileira fazer um forte ajuste fiscal por meio do corte de gastos, bem como de outras medidas recessivas supostamente para tentar controlar o crescimento da dívida interna bruta e líquida, em meio a uma recessão no inicio de 2015, era simplesmente nenhuma. E note que esse "ajuste fiscal" simplesmente falhou. Desde que as políticas contracionistas começaram a ser implementadas, o deficit público e a dívida pública (líquida e bruta) passaram a aumentar, evidenciando o fracasso de tais políticas para alcançar o seu objetivo declarado de reequilibrar as contas públicas. Particularmente, a própria agência de rating Standard \& Poor’s já apontava, no próprio relatório no qual explica o rebaixamento da nota do crédito em moeda externa brasileira por conta da suposta insustentabilidade da dívida líquida interna, que a situação das contas externas do país era bastante confortável (VERNENGO, 2015).

Em fevereiro de 2016, foi apresentada uma proposta, pelo mesmo partido que estava no governo que declarou que "acabou o dinheiro", de um plano de emergência para tirar o país da crise (PT, 2016). O plano era, em linhas gerais, bem razoável, pois basicamente implicava em fazer o exato oposto do que tinha sido feito pelo governo ${ }^{20}$. Porém, para completar a ironia da complexa relação entre o governo brasileiro da época, seu partido e as agências de rating, o plano cita uma proposta razoável de um economista da própria agência Standard \& Poor's, que recomenda uma redução da taxa básica de juros do Banco Central como solução para reduzir o crescimento do deficit público e da dívida interna ${ }^{21}$.

Podemos então concluir que "não acabou o dinheiro", pois tal coisa simplesmente não acontece no mundo real de países de moeda soberana como o Brasil. O que houve então? Não há espaço aqui para tratar apropriadamente dessa questão. Mas está cada vez mais claro que o real motivo da drástica virada da política econômica como um

${ }^{20}$ O ponto fraco da proposta está na ideia de que seria recomendável “a utilização de parcela das reservas internacionais em investimentos públicos, associada a recursos do orçamento corrente e créditos internacionais" (PT, 2016, p. 5). Na medida em que investimentos públicos têm, em geral, baixo conteúdo importado, não há a menor necessidade de se reduzir o cinturão protetor de reservas externas nem do governo se endividar em moeda estrangeira sem necessidade.

21 “Até mesmo o economista-chefe para a América Latina da Standard \&Poor's, Joaquín Cottani, insuspeito de heterodoxia, propôs a redução imediata da taxa Selic dos atuais 14,25\% para 7,25\% anuais, com o propósito de derrubar o deficit nominal brasileiro para 2,5\% do PIB até o final de 2017” (PT, 2016, p.4). 
todo a partir de 2015, que está produzindo uma profunda recessão na economia brasileira, sempre esteve ligado à tentativa de resolver o conflito distributivo gerando desemprego em massa com objetivo de criar um clima favorável a reformas que levem à redução do tamanho e do papel do Estado na economia. Nesse sentido, a política econômica introduzida no Brasil a partir de 2015 e que continuou após o golpe parlamentar que depôs o governo anterior tem sido muito bem sucedida e teve sua continuidade garantida (sobre esse conflito distributivo ver SERRANO e MELIN, 2016; MELIN e SERRANO, 2017; e SUMMA e SERRANO, 2017).

É evidente que, para os que apoiam tal agenda, a noção de que "acabou o dinheiro" é muito útil. Mas para os que defendem que o Brasil tenha também algum projeto nacional de desenvolvimento ${ }^{22} \mathrm{o}$ apego a essa noção tão difundida quanto equivocada praticamente garante que a política de desenvolvimento continuará sendo sabotada pela política macroeconômica.

\section{REFERÊNCIAS}

BCB - BANCO CENTRAL DO BRASIL. Relatório de Inflação, v. 1, n. 1, p. 1-97, jun. 1999.

BCB - BANCO CENTRAL DO BRASIL. Gestão da dívida mobiliária, operações de mercado aberto e swap cambial. Brasília: BCB, Diretoria de Política Econômica, 2015.

BCB - BANCO CENTRAL DO BRASIL. Nota de esclarecimento. 16/07/2013. Disponível em: $<$ https://www.bcb.gov.br/pt-br/\#!/c/notas/14785>.

BIANCARELLI, A. O setor externo da economia brasileira, depois da bonança e da tempestade. Revista Política Social e Desenvolvimento, ano 3, n. 23, out. 2015.

BINDSEIL, U. The operational target of monetary policy and the rise and fall of reserve position doctrine. Working Paper Series, European Central Bank, n. 372, 2004.

CARVALHO, F. J. C. de et al. Economia Monetária e Financeira: Teoria e Política. Rio de Janeiro: Campus, 2007.

DE REZENDE, F. C. The nature of government finance in Brazil. International Journal of Political Economy, v. 38, n. 1, p. 81-104, 2009.

HUFFPOST BRASIL. "Após dizer que 'acabou o dinheiro', Levy defende corte no orçamento e ajuste fiscal". Huffpost Brasil, Notícias, 25/05/2015. Disponível em:<http://www.huffpostbrasil.com/2015/05/25/ministros-defendem-ajuste_n_7437312.html>. Acesso em: 25 jun. 2016.

JÁCOME et al. Central Bank credit to the government: whatcan we learn from international practices? IMF Working Paper, WP/12/16, 2012.

LAVOIE, M. The monetary and fiscal nexus of neo-chartalism: a friendly critique. Journal of Economic Issues, v. 47, n. 1, p. 1-32, 2013.

${ }^{22}$ Sobre a questão do projeto nacional de desenvolvimento ver Medeiros (2017). 
LAVOIE, M. Post-Keynesian Economics: New Foundations. Edward Elgar Publishing, 2014.

LEISTER, M D; MEDEIROS, O L. Relacionamento entre autoridade fiscal e autoridade monetária: a experiência internacional e o caso brasileiro. Texto para Discussão, Tesouro Nacional, n. 13, 2012.

LERNER, A. Money as a creature of the state. The American Economic Review, v. 37, n. 2, p. 312-317, 1947.

LERNER, A. Economics of employment. New York: McGraw-Hill, 1951.

MEDEIROS, C. A Economia Brasileira no novo milênio: Do neoliberalismo ao desenvolvimentismo ao neoliberalismo. Revista de Economia Contemporânea, v. 21, n. 1, jan./abr. 2017.

MELIN, L.; SERRANO, F. Brazil's Neoliberal u-turn: wishful thinking in the face of class antagonism. The Bullet, E-bulletin 1352, January 6, 2017. Disponível em: <http://socialistproject. ca/bullet/1352.php>. Acesso em: 12 fev. 2017.

MOSLER, W. Soft Currency Economics. West Palm Beach, 2008 [1995]. Disponível em: <http:// moslereconomics.com/mandatory-readings/soft-currency-economics/>

PT - PARTIDO DOS TRABALHADORES. O futuro está na retomada das mudanças. PT, Diretório Nacional, 2016. Disponível em: <http://www.pt.org.br/wp-content/uploads/2016/02/O-futuro-est---na-retomada-das-mudan--as.pdf>. Acesso em: 12 ago. 2016.

PIVETTI, M. An essay on money and distribution. London: Macmillan, 1991.

ROUSSEFF, D. Entrevistaa Glenn Greenwald. The Intercept, 19/05/2016. Disponível em: <https://www.youtube.com/watch?v=_EaIMNshBBA>. Acesso em 19 ago. 2016.

SANTIAGO, M. Limites e procedimentos da política monetária: evidências do Brasil e dos EUA. nos anos 2000. Tese (Doutorado em Economia) - Instituto de Economia, Universidade Federal do Rio de Janeiro, Rio de Janeiro, 2012.

SERRANO, F. “A economia Americana, o padrão "dólar-flexível” e a expansão mundial nos anos 2000". In: FIORI, J.; SERRANO, F. E.; MEDEIROS, C. O mito do colapso americano. Rio de Janeiro: Editora Record, 2008.

SERRANO, F.; BRAGA, J. O mito da contração fiscal expansionista durante o governo Clinton. Economia e Sociedade, v. 15, p. 213, 2006.

SERRANO, F.; SUMMA, R. Mundell-Fleming without the LM curve: exogenous interest rate in an open economy. Review of Keynesian Economics, v. 3, p. 248-268, 2015.

SERRANO, F.; SUMMA, R. Uma sugestão para simplificar a teoria da taxa de juros exógena. Ensaios FEE, v. 34, p. 383-406, 2013.

SERRANO, F.; MELIN, L. Aspetti politici della disoccupazione: las voltaneo liberista in Brasile. Critica Marxista, v. 1, 2016.

SUMMA, R.; SERRANO, F. Distribution and Conflict inflation in Brazil under inflation targeting, 1999-2014. Review of Radical Political Economics, Forthcoming, 2017.

SHEARD, P. Repeat After me: banks cannot and do not "lend out" reserves. Ratings Direct, Standard \& Poors, 13/08/2013.

TESOURO NACIONAL. Plano Anual de Financiamento. Dívida pública federal. Brasília: Secretaria do Tesouro Nacional, n. 15, 2015. 
TESOURO NACIONAL. Relatório anual do Tesouro Nacional 2015. Brasília: Secretaria do Tesouro Nacional, n. 13, 2016.

VERNENGO, M. From BBB-razil to BB+razil or the meaning of investment grade. Naked Keynesianism, 11/09/2015. Disponível em: <http://nakedkeynesianism.blogspot.com.br/2015/09/ from-bbb-razil-to-bbrazil-or-meaning-of.html>. Acesso em: 19 out. 2015.

WRAY, R. Trabalho e moeda hoje: a chave para o pleno emprego e a estabilidade dos preços. Rio de Janeiro: Editora UFRJ/Contraponto Editora, 2003.

YOSHIMOTO, N. Afinal o que é Risco-país? Disclosure das Transações Financeiras, ano IX, ed. 100, mar. 2004. 